\title{
Properties of High Temperature Oxidation of Heat-resistant Steel with Aluminium and Copper
}

\author{
Hong LI ${ }^{1}$, Chengzhi ZHAO ${ }^{1,3}{ }^{*}$, Tao YAN ${ }^{2}$, Chao DING ${ }^{2}$, Hexin ZHANG $^{1,3}$, \\ Fengchun JIANG ${ }^{1,3}$
}

\author{
${ }^{1}$ College of Materials Science and Chemical Engineering, Harbin Engineering University, No. 145 Nantong Avenue, \\ Harbin, Heilongjiang, 150001, China \\ ${ }^{2}$ Technical Department, Jiangsu Province Yancheng Shengtai Valve Co.,Ltd., No. 18 Tinghu New Area Dongting Road, \\ Yancheng, Jiangsu, 224051, China \\ ${ }^{3}$ Key Laboratory of Superlight Materials and Surface Technology of Ministry of Education, Harbin Engineering \\ University, No. 145 Nantong Avenue, Harbin, Heilongjiang, 150001, China
}

crossref http://dx.doi.org/10.5755/j01.ms.25.4.19559

Received 26 November 2017; accepted 16 July 2018

\begin{abstract}
The research is focused on a novel aluminum and copper-containing heat-resistant steel. The steel was designed by the material performance simulation software JmatPro, performed high-temperature oxidation tests at $650{ }^{\circ} \mathrm{C}$ and $700{ }^{\circ} \mathrm{C}$ atmospheric conditions, and analyzed the high-temperature oxidation processes and its mechanisms. The phase transtions and surface morphology of the oxide films were studied using X-ray diffraction (XRD), electron microscopy (SEM) and energy-dispersive X-ray spectroscopy (EDS). The results showed that the equilibrium phase of the test steel is composed of $\gamma$ phase and $\delta$ phase at $1050{ }^{\circ} \mathrm{C}$ and tranforms to tempered martensite and $\delta$-Fe mixed structure after heat treatment. The preferential oxidation of $\mathrm{Fe}$ and $\mathrm{Cr}$ and the internal oxidation of $\mathrm{Al}$ occurred during the high temperature oxidation of the test steel. The oxide films were formed with various shape and weak bonding properties after high-temperature oxidation at $650^{\circ} \mathrm{C}$. To the contrary, the oxide films more regular and evenly distributed, and has a certain protective effect after high-temperature oxidation at $700{ }^{\circ} \mathrm{C}$. The oxide films were divided into two layers, $\mathrm{Fe}_{2} \mathrm{O}_{3}$ is main element in the outer layer, the inner layer is mainly consisting the oxide of $\mathrm{Cr}$. However, the addition of $\mathrm{Cu}$ element can promote the diffusion of $\mathrm{Al}$ and $\mathrm{Si}$ elements, which is beneficial to the formation of $\mathrm{Al}_{2} \mathrm{O}_{3}$ and $\mathrm{SiO}_{2}$ protective oxide films and excellent in high temperature oxidation resistance.
\end{abstract}

Keywords: JmatPro, heat-resistant steel, high-temperature oxidation, oxide films, morphology.

\section{INTRODUCTION}

"Energy, Environment and Development" are the three major themes that human face in the 21 st century. At the same time, in the face of global energy shortage [1], environmental pollution, global climate and other issues, ultra-supercritical units have become the main development direction of thermal power generating units $[2,3]$. How to improve the thermal efficiency of the unit has always been a key issue [4]. The ultra-supercritical technology which continuously improves the steam pressure and the steam temperature of the boiler can not only improve the thermal efficiency of the unit, but also solve the problems of energy, environment, climate and development are an effective means $[5,6]$. Now, the unit parameters of all countries in the world are developing to ultra-supercritical parameters $\left(600{ }^{\circ} \mathrm{C}, 30 \mathrm{MPa}\right)$ or even higher $[7,8]$. The United States, Europe, Japan, Britain, China and some other countries have all started the research of advanced ultra-supercritical technology at $700{ }^{\circ} \mathrm{C}$. With the continuous improvement of unit parameters, this poses more stringent requirements for heat-resistant steel for boilers. It is required that the boiler heat-resistant steel should have excellent high-temperature mechanical properties, high temperature oxidation resistance and high temperature molten salt corrosion resistance properties, processing performance and low cost and other characteristics $[9,10]$, due to the long-term service under high temperature and high pressure, at the same time, the corrosion and oxidation of $\mathrm{NaCl}, \mathrm{Na}_{2} \mathrm{SO}_{4}$ in the combustion chamber failed rapidly [11]. At the same time, it should have good welding performance and thermal conductivity.

At present, the service life of the heat-resistant steel is mainly improved by optimizing the chemical composition of the heat-resistant steel and improving the heat treatment process [12-15]. In the previous research, some researchers increased the high temperature oxidation resistance and high-temperature mechanical properties by adding $\mathrm{Al}$ element to the heat-resisting steel, and a lot of researches have been done [16], but at the same time, Al will cause the alloy's poor liquidity, the increase of the hard and brittle, which is not conducive to machining defects $[17,18]$. However, the addition of $\mathrm{Cu}$ in the steel can not only improve the corrosion resistance of the steel, the cold workability and fatigue resistance of the alloy, but also improve the fluidity of the alloy liquid [19].

In this paper, the composition of new heat-resistant steel was designed by material property simulation software JmatPro [20-22] and the corresponding database. Al and $\mathrm{Cu}$ elements were added to improve the high temperature

\footnotetext{
* Corresponding author. Tel.: +86-13895718408.

E-mail address: zhaochengzhi@hrbeu.edu.cn (C. Zhao)
} 
oxidation resistance and molten salt corrosion resistance of steel. A new heat-resistant steel containing $\mathrm{Al}, \mathrm{Cu}$ was made through casting process. According to the phase transition process and microstructure of the test steel, the oxidation kinetics curves of the test steel at $650{ }^{\circ} \mathrm{C}$ and $700{ }^{\circ} \mathrm{C}$ in air, the surface morphology, phase and morphology of the oxide film were analyzed. The oxidation kinetic curves were nonlinearly fitted by mathematical models and their oxidation rate constants were obtained. The high temperature oxidation activation energy was calculated by the Arrhenius relationship. Its high temperature oxidation behavior was analyzed and the high temperature oxidation resistance of the materials was evaluated. All of this provide theoretical and experimental basis for the development of heat-resistant steel.

\section{MATERIALS AND METHODS}

\subsection{Materials}

In this experiment, a new high-vacuum arc melting furnace (Shenyang Scientific Instrument Co., Ltd.) was used to smelt a new heat-resistant steel containing aluminum and copper. After the heat-resistant steel is melting, the chemical composition of steel's was measured using the directreading spectrometer (Spectro MAXx from Germany) as shown in Table 1.

\subsection{Experimental method}

The test steel was preheated in a high temperature box resistance furnace RJX-8-13: $1050{ }^{\circ} \mathrm{C} \times 45 \mathrm{~min}$ air cooled $+770{ }^{\circ} \mathrm{C} \times 2 \mathrm{~h}$ cooled to $300{ }^{\circ} \mathrm{C}$ in the furnace, and then air cooled to room temperature. The test steel were cut into small pieces approximately $20 \mathrm{~mm} \times 10 \mathrm{~mm} \times 2 \mathrm{~mm}$ using wire cutting, polished with sandpaper and cleaned twice with ethanol and acetone, respectively. The kinetic curves of high temperature oxidation was determined by the cyclic oxidation test and discontinuous weighing method. The test would last $200 \mathrm{~h}$ in $650{ }^{\circ} \mathrm{C}$ and $700{ }^{\circ} \mathrm{C}$ in static air. And then test steels are take out from the furnace to do the test after $1 \mathrm{~h}, 4 \mathrm{~h}, 7 \mathrm{~h}, 10 \mathrm{~h}, 30 \mathrm{~h}, 50 \mathrm{~h}, 70 \mathrm{~h}, 90 \mathrm{~h}, 110 \mathrm{~h}, 140 \mathrm{~h}$, $170 \mathrm{~h}, 200 \mathrm{~h}$, respectively. After cooling to room temperature, the weight is weighed using an electronic analytical balance whose precision is $1 \times 10^{-4} \mathrm{~g}$. The oxidation kinetics curve is drawn according to the oxidation weight per unit and oxidation time.

The test steel's microstructure observation is after its corrosion in an etchant, which contains $4 \mathrm{~g}$ picric acid $+5 \mathrm{ml}$ hydrochloric acid $+100 \mathrm{ml}$ alcohol. The samples are put in the alumina crucible to do the high temperature oxidation test in MaoFu-heating resistance furnace SM-28-10. There are $10 \mathrm{~mm}$ holes on the door of the furnace to ensure the furnace has enough oxygen. Before each test, the alumina crucible must be heated to constant weight. The sample should be taken out at regular intervals to be weighed. The three samples should be selected for parallel experiment and the average should be taken. The microstructure and high temperature oxidation surface and cross section morphology of the test steel were observed using field emission scanning electron microscope (MX2600FE). The composition of the steel were studied by energy dispersive spectrometer (EDS), X-ray diffraction (XRD) technique was carried out to identify oxide film of the test steel after being oxidized at $650{ }^{\circ} \mathrm{C}$ and $700{ }^{\circ} \mathrm{C}$ in air for $200 \mathrm{~h}$. with $\mathrm{Cu} \mathrm{K} \alpha$ radiation $(\lambda=1.5406 \AA)$ and $2 \theta$ scan between $20^{\circ}$ to $90^{\circ}$.

\section{RESULTS AND DISCUSSION}

\subsection{The thermodynamic equilibrium phase and microstructure of the test steel}

After the calculation of the material performance by simulation software JmatPro, the relationship curve between the amount of precipitation of each phase in the test steel and the temperature is drawn, as shown in Fig. 1.

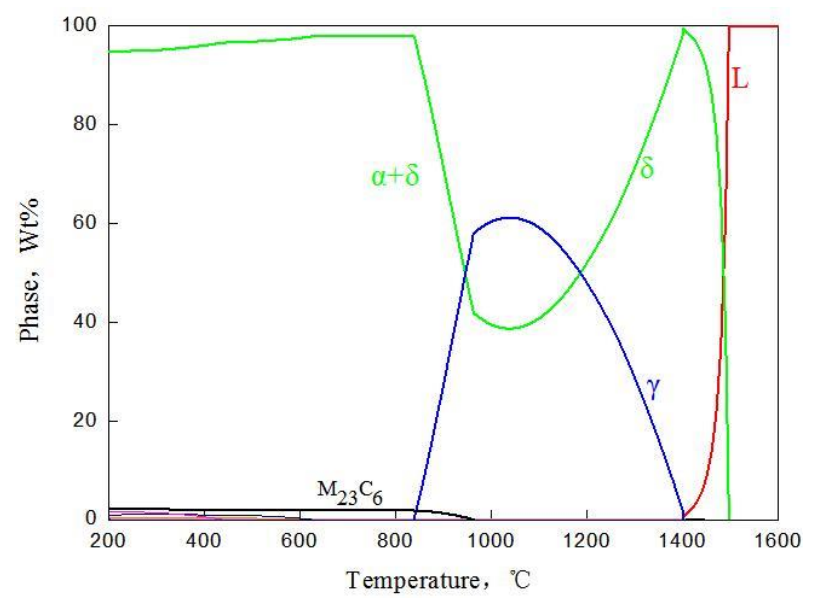

a

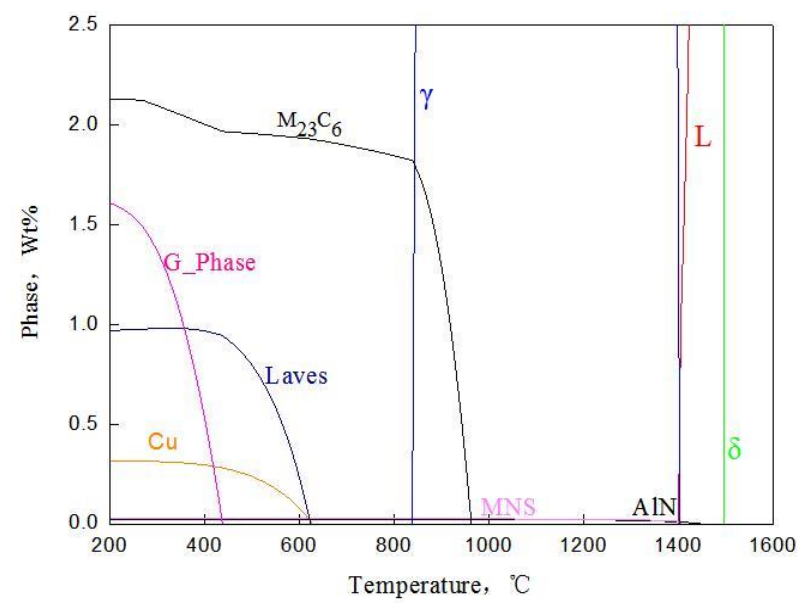

b

Fig. 1. The relationship between the precipitation amount of each phase of aluminum, copper-containing heat-resistant steel and temperature: $\mathrm{a}$-complete curve; $\mathrm{b}$-partial map

As can be seen from Fig. 1, the equilibrium phase of the test steel build up by $\alpha, \mathrm{M}_{23} \mathrm{C}_{6}, \mathrm{G}$ phase, Laves phase and a small amount of $\mathrm{Cu}$ phase and $\mathrm{AlN}$, MNS phase. By JmatPro analysis, carbides $\mathrm{M}_{23} \mathrm{C}_{6}$ mainly contains chromium and molybdenum alloy elements, $\mathrm{G}$ phase was nickel, manganese, silicon intermetallic compounds, Laves phase was molybdenum, iron, chromium intermetallic compounds.

Analysis of the phase diagram of the test steel shows that the test steel has a melting point at $1400{ }^{\circ} \mathrm{C}$ and the crystallization process is as follows: 
Table 1. Chemical compositions of experimental steels (mass fraction \%)

\begin{tabular}{|c|c|c|c|c|c|c|c|c|c|c|c|c|c|}
\hline Element & $\mathrm{Al}$ & $\mathrm{Cr}$ & $\mathrm{Mn}$ & $\mathrm{Ni}$ & $\mathrm{Mo}$ & $\mathrm{Cu}$ & $\mathrm{Si}$ & $\mathrm{V}$ & $\mathrm{Nb}$ & $\mathrm{C}$ & $\mathrm{N}$ & $\mathrm{S}$ & $\mathrm{P}$ \\
\hline Content & 1.33 & 9.85 & 1.05 & 1.08 & 0.85 & 0.31 & 0.24 & 0.29 & 0.08 & 0.11 & 0.008 & 0.009 & 0.008 \\
\hline
\end{tabular}

the homogenization transformation $(\mathrm{L} \rightarrow \delta)$ begins to crystallize $\delta$ ferrite from the liquid phase in the first, with a small amount of AlN precipitated subsequently, and there is no significant changes when the crystallization are completed at $1497^{\circ} \mathrm{C}$. When the $\delta$ ferrite mass fraction reaches $99 \%$, the remaining liquid and $\delta$ phases begin to undergo peritectic transformation $(\mathrm{L}+\delta \rightarrow \gamma)$ to generate $\gamma$ phase until the liquid phase disappears, and then $\gamma$ phase was formed by allotropic transformation $(\delta \rightarrow \gamma)$. $\gamma$ phase accounts for $61 \%$ and $\delta$ phase accounts for $38 \%$ at $1020{ }^{\circ} \mathrm{C}$. With the decrease of temperature, the allotropic transformation of $\gamma$ phase to $\alpha$ phase ferrite begins to occur until $840{ }^{\circ} \mathrm{C}$; at the same time, the carbides $\mathrm{M}_{23} \mathrm{C}_{6}$ began to precipitate from the $\gamma$ phase when the temperature was lower than $960{ }^{\circ} \mathrm{C}$. The $\mathrm{Cu}$-rich phase and the Laves phase precipitated from the remaining $\delta$ phase at $620{ }^{\circ} \mathrm{C}$, and the $\mathrm{G}$ phase began to precipitate at $440{ }^{\circ} \mathrm{C}$ finally.

Fig. 2 shows the results of analysis of scanning electron microscopy and element distribution of the steels after heat treatment. It can be concluded that: the test steel after heat treatment is the high temperature tempered martensite and a small amount of $\delta$-Fe mixed tissue, the element distribution results indicated that the iron-rich and chromium intermetallic compounds, suspected as Laves phase, were found at martensite and the boundary of $\delta$-Fe (point A). There were dark lumps (point B) in the $\delta$-Fe structure, doubt is AlN phase. Similarly, an irregular phase (point D) was found inside the $\delta$-Fe structure, which is suspected as a nickel-manganese-silicon intermetallic compound named $\mathrm{G}$ phase; and round granular phase precipitates at the original austenite grain boundaries (point $\mathrm{C}$ ), is found to be like $\mathrm{M}_{23} \mathrm{C}_{6}$ type carbide, and the results of energy spectrum analysis and JmatPro calculation is consistent. However, due to instrument limitations, the energy spectrum analysis is insufficient to determine the phase composition.

\subsection{High temperature oxidation kinetics}

The oxidation kinetics curves of the test steel after being oxidized at $650{ }^{\circ} \mathrm{C}$ and $700{ }^{\circ} \mathrm{C}$ for $200 \mathrm{~h}$ are shown in Fig. 3 . No peeling off of the oxide film was observed during the test, indicating that the oxidation resistance of the test steel is good. The average oxidation rate of the test steel at $650{ }^{\circ} \mathrm{C}$ is $0.0716 \mathrm{~g} / \mathrm{m}^{2} \mathrm{~h}$, and the average oxidation rate at $700{ }^{\circ} \mathrm{C}$ is $0.0913 \mathrm{~g} / \mathrm{m}^{2} \mathrm{~h}$. Based on the oxidation resistance of the superalloy and the high temperature protective coating [23], the average oxidation rates of the test steels were all less than the first level of full oxidation resistance $\left(<0.1 \mathrm{~g} / \mathrm{m}^{2} \mathrm{~h}\right)$.

After the oxide film completely covered the metal surface, the metal and the atmosphere is separated during the high temperature oxidation process, so ions and electrons must be transmitted through the oxide film to continue the reaction.

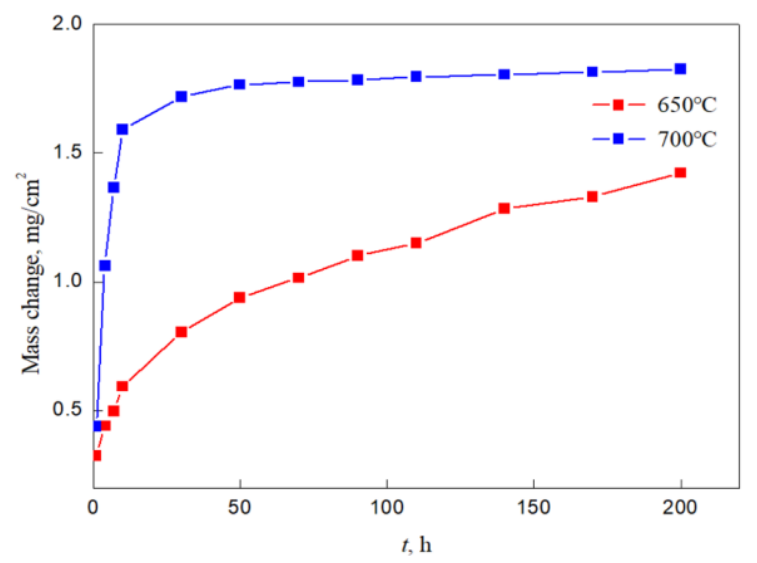

Fig. 3. Test steel's high temperature oxidation dynamic curve

Oxygen in the atmosphere diffuses through the oxygen/oxide film interface, and the physically adsorbed molecular oxygen becomes atomic oxygen, which undergoes chemical adsorption to become $\mathrm{O}^{-}$, and then is incorporated into the oxide lattice in the form of $\mathrm{O}^{2-}$, whereas in the oxide film/metal interface, the metal is ionized into $\mathrm{M}^{2+}$, and some metal cations migrate to the oxygen/oxide film interface through the oxide film, or oxygen anions migrate to the oxide film/metal interface through the oxide film to make the oxidation reaction continued [24]. In this experiment, due to the atmospheric environment, oxygen in the atmosphere transmit to the surface of the oxide film is very fast, and electron or electron hole transport in the oxide film is far greater than the number of ion transport, so the metal cations, oxygen anions through the transfer of the oxide film becomes a control step of the oxidation process. The oxidation kinetics curve shows that the oxidation rate is faster at the initial oxidation stage because the oxide film has not fully covered the metal surface, and the increase of temperature is favorable for the ions or electrons to pass through the oxide film to accelerate the oxidation rate.

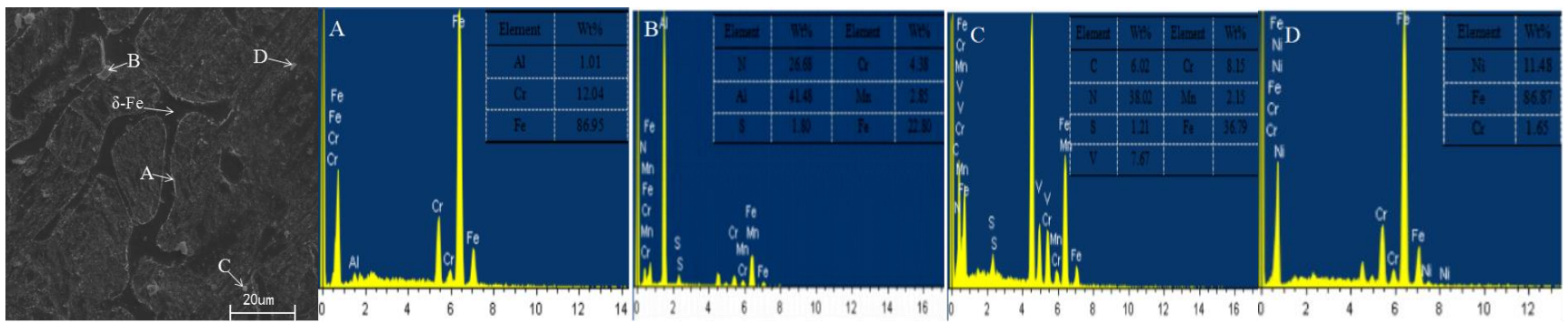

Fig. 2. Microstructure and element distribution of test steels after heat treatment 
Although the increase of the temperature aggravates oxidation degree, but it is conducive to the rapid formation of dense and complete oxide film, and slowing the oxidation reaction. During the oxidation process at $650{ }^{\circ} \mathrm{C}$, the oxidation rate of the test steel is slow, and a dense and continuous protective oxide film can not be formed as soon as possible. Therefore, the kinetic curve shows a gradual increase in weight, while at $700{ }^{\circ} \mathrm{C}$, the oxidation rate obviously accelerated and formed a protective oxide film quickly. Therefore, the rate of weight gain per unit area in the first $50 \mathrm{~h}$ was large, and the weight gain showed a stable trend after $150 \mathrm{~h}$. The main reason was the temperature has improved the migration speed of positive and negative ions through the oxide film at the initial stage of oxidation.

\subsection{Oxide phase}

The XRD phase analysis of the surface oxide film of the test steel after oxidation for $200 \mathrm{~h}$ under the atmospheric environment was carried out. The results are shown in Fig. 4. It can be seen that the oxide film on the surface of the test steel mainly consists of $\mathrm{Fe}_{2} \mathrm{O}_{3}$ and some other oxides, and the diffraction peak of the test steel is not found, indicating that the oxide film has completely covered the substrate. The diffraction peak of the test steel after oxidation at $700{ }^{\circ} \mathrm{C}$ for $200 \mathrm{~h}$ is stronger than that of $650{ }^{\circ} \mathrm{C}$, indicating that the oxidation is more serious, which is consistent with the result of oxidation kinetics analysis.

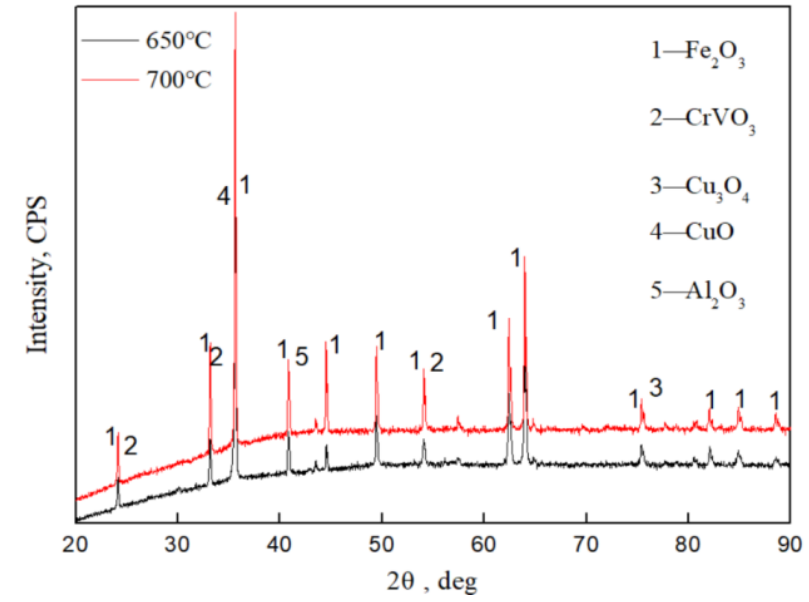

Fig. 4. XRD profile of the test steel's oxide film

\subsection{The surface of the oxide film and cross- sectional morphology}

Test steel after oxidizing $200 \mathrm{~h}$ at $650{ }^{\circ} \mathrm{C}, 700{ }^{\circ} \mathrm{C}$, the morphology of the oxide film surface is shown in Fig. 5.As can be seen from the figure, the surface oxide film morphology of the test steel is different. After being oxidized for $200 \mathrm{~h}$ at $650{ }^{\circ} \mathrm{C}$ (Fig. 5 a), the oxide film on the surface has different shapes which is massive, granular and small amount of stick. At the same time, the bonding between the oxide films is weaker and some are hollowed. Combined with the oxidation kinetics curve, it can be seen that the oxide film has a weak protective effect on the matrix and will cause the continuous oxidation of the material. However, when the test steel is oxidized for $200 \mathrm{~h}$ at $700{ }^{\circ} \mathrm{C}$ (Fig. 5 b), the surface of the oxide film is relatively flat without any obvious irregularities, and the shape of the oxide film is uniform, well-distributed and dense which can protect the material. The EDS analysis showed that the main oxide of the test steel was mainly $\mathrm{Fe}_{2} \mathrm{O}_{3}$, which was consistent with the phase analysis of the oxide film.
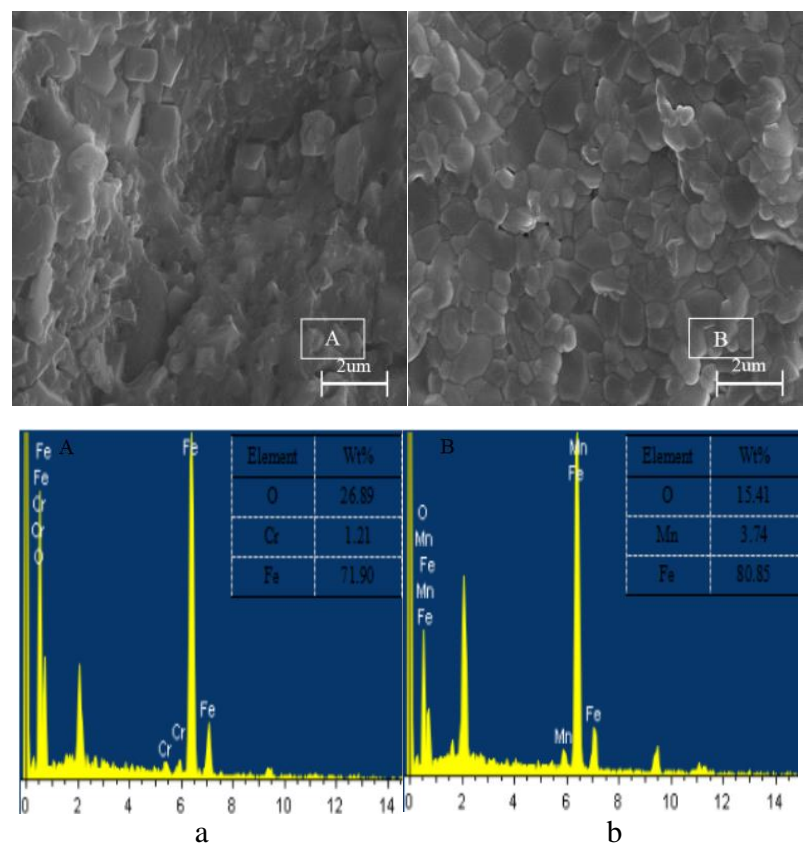

Fig. 5. Surface morphology of high-temperature oxide film of test steel: a-surface morphology of oxide film at $650{ }^{\circ} \mathrm{C}$; b-surface morphology of oxide film at $700{ }^{\circ} \mathrm{C}$; A.B: Analysis of regional elements

Test steel after high temperature oxidation $200 \mathrm{~h}$ in the atmospheric environment, the oxide film cross-sectional morphology and EDS analysis is shown in Fig. 6.

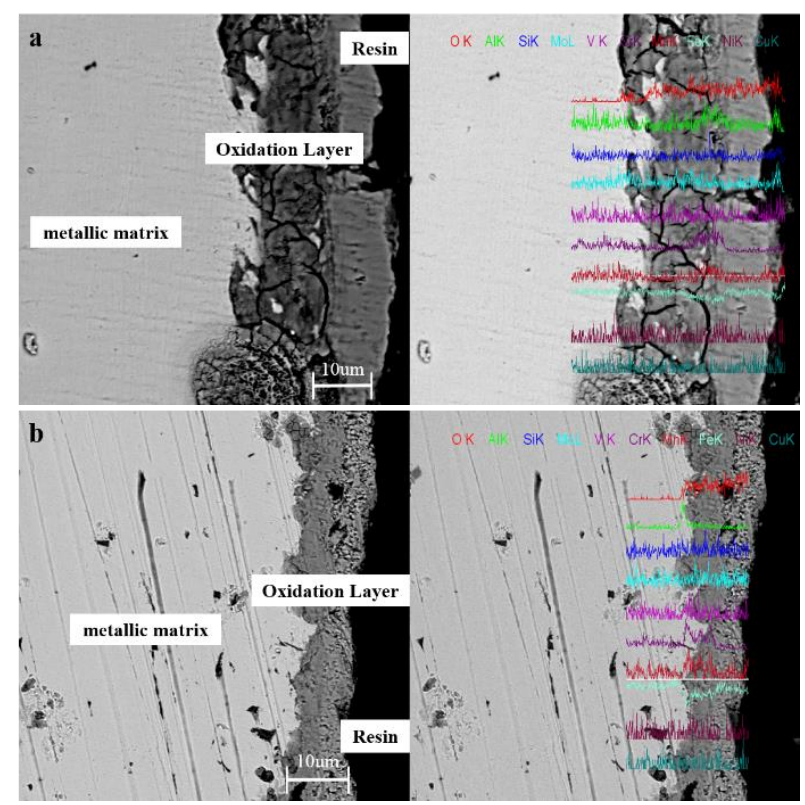

Fig. 6. The high temperature oxidation section morphology and EDS analysis of test steel: a-morphology and elemental analysis of the oxidation profile at $650{ }^{\circ} \mathrm{C} ; \mathrm{b}-$ morphology and elemental analysis of the oxidation profile at $700{ }^{\circ} \mathrm{C}$

As can be seen from the figure, the oxide film is divided into two layers after high temperature oxidation, the outer layer is mainly composed of $\mathrm{Fe}$, the inner layer is mainly $\mathrm{Cr}$, 
and the inside of the oxide film has some cracks and voids;oxidation film with high temperature oxidation at $650{ }^{\circ} \mathrm{C}$ has a poor adhesion with the matrix and have deeper cracks (Fig. 6 a), which increases the diffusion channels of external oxygen atoms and the matrix can be further oxidized, which is consistent with the oxidation kinetics curve; the oxide film formed at $700{ }^{\circ} \mathrm{C}$ (Fig. 6 b) is dense and continuous with no deep cracks and voids inside, which has a certain protective effect on the substrate.

\subsection{High temperature oxidation activation energy}

The oxidation kinetics curves of the test steels are nonlinearly fitted by the mathematical model of the kinetic parabolic equation of high temperature oxidation

$(\Delta \mathrm{W})^{2}=K_{p} t+C[25-27]$,

where $\Delta W$ is the weight change per unit area of the test steel; $t$ is the oxidation time; $K_{\mathrm{p}}$ is the growth rate of the oxide film; $C$ is the integral constant. The fitting results are shown in Table 2. By comparing the results with the data of the growth rate constants of oxide films, it is found that the increase of temperature accelerates the oxide film's grow of the test steel.

Table 2. The fitting relationship between oxidation gain and time under different temperature of test steel

\begin{tabular}{|c|c|}
\hline Temperature & Expression \\
\hline $650^{\circ} \mathrm{C}$ & $(\Delta \mathrm{W})^{2}=0.01037 t+0.18654$ \\
\hline $700^{\circ} \mathrm{C}$ & $(\Delta \mathrm{W})^{2}=0.02756 t+0.18655$ \\
\hline
\end{tabular}

High temperature oxidation activation energy can explain the pros and cons of high temperature oxidation resistance of materials, according to Arrhenius's law [28, 29]:

$K_{p}=A \exp (-Q / R T)$,

where $K_{\mathrm{p}}$ is the growth rate constant of oxide film; $Q$ is the activation energy of oxidation reaction; $R$ is the gas constant, $T$ is absolute temperature and $A$ is constant. According to the fitting results in Table 2, the growth rate constants and absolute temperature of the oxide film are brought into the Arrhenius law expression, and the constants and the oxidation activation energies of the steel are obtained, and the relationship between the growth rate constant of the oxide film and the absolute temperature is obtained.

$$
\begin{aligned}
& 0.01037=\operatorname{Aexp}\left(\frac{-Q}{8.314 \times 923.15}\right) ; \\
& 0.02756=\operatorname{Aexp}\left(\frac{-Q}{8.314 \times 973.15}\right) .
\end{aligned}
$$

The parameters and the relationship between parabolic oxide film growth rate constant and temperature was obtained through the Eq. 3 and Eq. 4 as shown in Table 3.

Table 3. The high temperature oxidation parameters and expressions of test steel

\begin{tabular}{|c|c|c|}
\hline$A, \mathrm{mg}^{2} / \mathrm{cm}^{4} \cdot \mathrm{h}$ & $Q, \mathrm{~kJ} / \mathrm{mol}$ & Expression \\
\hline $1.9 \times 10^{6}$ & 146 & $K_{p}=1.9 \times 10^{6} \exp \left(\frac{-17561}{T}\right)$ \\
\hline
\end{tabular}

The calculation results show that the designed high temperature oxidation activation energy of novel aluminum, copper heat-resistant steel is $146 \mathrm{~kJ} / \mathrm{mol}$, which is higher than the Co-Al-W alloy whose abbreviation is 2Ti in [28]. And shows excellent high-temperature oxidation resistance performance.

\subsection{Discussion}

Based on the analysis of the experimental results, it can be concluded that due to the smooth surface of the test steel and the oxidation process controlled by the chemical reaction mechanism during the initial oxidation stage, the oxidation rate is extremely high and the weight gain is obvious. With the continuous of the oxidation progresses, when a complete oxide film is formed on the surface, the oxidation rate gradually decreases and the weight gain slows down. At this time, the oxidation is controlled by the elemental diffusion mechanism. As shown in Fig. 3, due to the influence of different mechanisms during different stages of oxidation, the rate of matrix reacted with air at the initial stage is significantly higher than the latter ions diffusion [30]. At the initial stage of oxidation, the selective oxidation of $\mathrm{Fe}$ and $\mathrm{Cr}$ occurred mainly due to the high content of $\mathrm{Fe}$ and $\mathrm{Cr}$ [31], and at the same time, the activity of Al was higher and internal oxidation occurred [32]. Under the high temperature of $700{ }^{\circ} \mathrm{C}$, the migration rate of positive and negative ions was accelerated, what's more, $\mathrm{Cu}$ element can promote the diffusion of $\mathrm{Al}$ element [33]. A protective oxide film of $\mathrm{Al}_{2} \mathrm{O}_{3}$ is formed rapidly by the diffusion of oxygen and $\mathrm{Al}[34,35]$. As shown in Fig. 6 b, EDS analysis results shows, the inner layer of the oxide film has a thin layer of $\mathrm{Al}_{2} \mathrm{O}_{3}$, which can effectively prevent oxygen from diffusing inward to protect the substrate [36]. According to the distribution of $\mathrm{Si}$ element, it can be concluded that $\mathrm{Cu}$ element can promote the diffusion of $\mathrm{Si}$ element, thus forming $\mathrm{SiO}_{2}$ oxide to increase the compactness of the inner layer $\mathrm{Cr}_{2} \mathrm{O}_{3}$ oxide film. With the continuous oxidation process, the iron ions in the matrix continue to diffuse outward to form the double oxide film whose main content is $\mathrm{Fe}_{2} \mathrm{O}_{3}$ [37], while the outward diffusion of iron ions caused the formation of vacancies. Finally a crack was formed.

\section{CONCLUSIONS}

The new heat-resistant steel was designed at $1050{ }^{\circ} \mathrm{C}$, the equilibrium phase is constituted by the $\gamma$ phase and $\delta$ phase. It will become a high temperature tempered martensite and $\delta$-Fe mixed microstructure after the heat treatment, which is consistent with the microstructure analysis of the test steel. The oxidation resistance levels of all samples at $650{ }^{\circ} \mathrm{C}$ and $700{ }^{\circ} \mathrm{C}$ for $200 \mathrm{~h}$ belong to the standard of complete oxidation $\left(<0.1 \mathrm{~g} / \mathrm{m}^{2} \mathrm{~h}\right)$, which is consistent with the service requirements of heat-resisting steel. The purpose of alloying was achieved. Oxidation kinetics curve follows the parabolic law, and the activation energy was $146 \mathrm{~kJ} / \mathrm{mol}$. The experiment indicates that: adding $\mathrm{Cu}$ to steel, diffusion of $\mathrm{Al}$ and $\mathrm{Si}$ elements can be promoted, the protective oxide films of $\mathrm{Al}_{2} \mathrm{O}_{3}$ and $\mathrm{SiO}_{2}$ can be formed on the surface. Meanwhile, the density of the $\mathrm{Cr}_{2} \mathrm{O}_{3}$ inner layer oxide film was increased. After high temperature oxidation, the oxide film is excellent in anti- 
spalling properties. The structure is divided into two layers. The outer layer is mainly composed of $\mathrm{Fe}_{2} \mathrm{O}_{3}$ and the inner layer is mainly composed of $\mathrm{Cr}$. At the same time, there is $\mathrm{Al}_{2} \mathrm{O}_{3}$ and $\mathrm{SiO}_{2}$ protective film layer, which play a protective role on the substrate, it has excellent antioxidation properties.

\section{Acknowledgments}

This research was Supported by The Fundamental Research Funds for the Central Universities of China(No.HEUCFP201719 and No.HEUCFP201731) and Science and technology plan projects in jiangsu province of China(NO.BE2017105).

\section{REFERENCES}

1. Beer, J.M. High Efficiency Electric Power Generation: the Environmental Role Progress in Energy \& Combustion Science 33 (2) 2007: pp. 107-134. https://doi.org/10.1016/j.pecs.2006.08.002

2. Ennis, P.J., Czyrska-Filemonowicz, A. Recent Advances in Creep-Resistant Steels for Power Plant Applications Sädhanā 28 (3) 2003: pp. 709-730. https://doi.org/10.1007/BF02706455

3. Hald, J., Viswanathan, V., Abe, F. Energy Drivers for Materials Research and Development Energy Materials: Materials Science \& Engineering for Energy Systems 1 (1) 2013: pp. $1-6$. https://doi.org/10.1179/174892306X102665

4. Abe, F. Precipitate Design for Creep Strengthening of $9 \% \mathrm{Cr}$ Tempered Martensitic Steel for Ultra-Supercritical Power Plants Science and Technology of Advanced Materials 9 (1) 2008: pp. $70-71$.

https://doi.org/10.1088/1468-6996/9/1/013002

5. Viswanathan, R., Henry, J.F., Tanzosh, J., Stanko, G., Shingledecker, J., Vitalis, B. U.S. Program on Materials Technology for Ultra-Supercritical Coal Power Plants Journal of Materials Engineering \& Performance 14 (3) 2005: pp. $281-292$.

https://doi.org/10.1361/10599490524039

6. Viswanathan, R., Bakker, W. Materials for Ultrasupercritical Coal Power Plants - Boiler Materials: Part 1 Journal of Materials Engineering \& Performance 10 (1) 2001: pp. $81-95$.

https://doi.org/10.1361/105994901770345394

7. Viswanathan, R., Purgert, R., Goodstine, S., Tanzosh, J., Stanko, G., Shingledecker, J.P. US Program on Materials Technology for Ultrasupercritical Coal-Fired Boilers In International Conference on Advances in Materials Technology 2008: pp. 1-15. https://doi.org/10.1361/cp2007epri0001

8. Viswanathan, R., Coleman, K., Rao, U. Materials for UltraSupercritical Coal-Fired Power Plant Boilers International Journal of Pressure Vessels \& Piping $83(11-12)$ 2006: pp. $778-783$.

https://doi.org/10.1016/j.ijpvp.2006.08.006

9. Zhao, X., Dang, Y., Yin, H., Lu, J., Yuan, Y., Yang, Z. Effect of Heat Treatment on the Microstructure of a Ni-Fe Based Superalloy for Advanced Ultra-Supercritical Power Plant Applications Progress in Natural Science:Materials International 26 (2) 2016: pp. 204-209. https://doi.org/10.1016/j.pnsc.2016.03.013

10. Zhong, Z.H., Gu, Y.F., Yuan, Y., Shi, Z. A new wrought $\mathrm{Ni}-\mathrm{Fe}$-base superalloy for advanced ultra-supercritical power plant applications beyond $700{ }^{\circ} \mathrm{C} \quad$ Materials Letters

2013: pp. $38-41$.

https://doi.org/10.1016/j.matlet.2013.07.060

11. Mahobia, G.S., Paulose, N., Singh, V. Hot Corrosion Behavior of Superalloy IN718 at 550 and $650{ }^{\circ} \mathrm{C}$ Journal of Materials Engineering and Performance $22(8)$ 2013: pp. $2418-2435$.

https://doi.org/10.1007/s11665-013-0532-0

12. Zhang, R., Zhang, C., Xia, Z., Yang, Z. Optimizing Control of Precipitates in T91 Ferritic Heat-Resistan Steel Acta Metallurgica Sinica 49 (9) 2013: pp. 1075-1080. https://doi.org/10.3724/SP.J.1037.2013.00178

13. Yang, K., Yan, W., Wang, Z., Shan, Y., Shi, Q. Development of a Novel Structural Materlal(SIMP Steel)for Nuclear Eouipment With Balanced Resistances to High Temperature, Radiation and Liquid Metal Corrosion Acta Metallurgica Sinica 52 (10) 2016: pp. 1207-1221. https://doi.org/10.11900/0412.1961.2016.00320

14. Chi, C., Yu, H., Dong, J. Strengthening Effect of Cu-rich Phase Precipitation in $18 \mathrm{Cr} 9 \mathrm{Ni} 3 \mathrm{CuNbN}$ Austenitic HeatResisting Steel Acta Metallurgica Sinica 24 (2) 2011: pp. $141-147$. https://doi.org/10.11890/1006-7191-112-141

15. Chi, C., Dong, J., Liu, W., Xie, X. 3DAP Investigation of Precipitation Behavior of Cu-Rich Phase in Super304H Heat Resistant Steel Acta Metallurgica Sinica 46(9) 2010: pp. $1141-1146$. https://doi.org/10.3724/SP.J.1037.2009.00853

16. Yamamoto, Y., Brady, M.P., Lu, Z.P., Liu, C.T., Takeyama, M., Maziasz, P.J. Alumina-Forming Austenitic Stainless Steels Strengthened by Laves Phase and MC Carbide Precipitates Metallurgical and Materials Transactions A 38 (11) 2007: pp. 2737-2746. https://doi.org/10.1007/s11661-007-9319-y

17. Spindler, S., Wittmann, R., Gerthsen, D., Lange, J., Brede, M., Klower, J. Dislocation Properties of Polycrystalline $\mathrm{Fe}-\mathrm{Cr}-\mathrm{Al}$ Alloys and Their Correlation with Mechanical Properties Materials Science and Engineering: A 289 (1-2) 2000: pp. 151-161. https://doi.org/10.1016/S0921-5093(00)00910-2

18. Song, J.L., Lin, S.B., Yang, C.L., Ma, G.C., Liu, H. Spreading Behavior and Microstructure Characteristics of Dissimilar Metals TIG Welding-Brazing Of Aluminum Alloy to Stainless Steel Materials Science and Engineering $A$ 509 (1-2) 2009: pp. 31-40. https://doi.org/10.1016/j.msea.2009.02.036

19. Takahashi, A., Iino, M. Microstructural Refinement by $\mathrm{Cu}$ Addition and Its Effect on Strengthening and Toughening of Sour Service Line Pipe Steels ISIJ International 36 (2) 1996: pp. $241-245$. https://doi.org/10.2355/isijinternational.36.241

20. Guo, Z., Saunders, N., Miodownik, A.P., Schillé, J.P. Modelling of Materials Properties and Behaviour Critical to Casting Simulation Materials Science \& Engineering A 413 (6) 2005: pp. $465-469$. https://doi.org/10.1016/j.msea.2005.09.036

21. Kattner, U.R. Efficient Phase Diagram Information and Computational Thermodynamics Journal of Phase Equilibria \& Diffusion 27 (2) 2006: pp. 126-132. https://doi.org/10.1007/s11669-006-0035-x

22. Saunders, N., Guo, Z., Li, X. Using JMatPro to Model Materials Properties and Behavior The Journal of The Minerals, Metals \& Materials Society $55(12)$ 2003: pp. $60-65$. https://doi.org/10.1007/s11837-003-0013-2 
23. HB5258-2000. Test Method for Determination of Oxidation Resistance of Steel and High-Temperature Alloys.

24. Li, M.Q. High Temperature Corrosion of Metals Beijing: Metallurgical Industry Press 2001: pp. 79-81.

25. Li, T.P. Metal High Temperature Oxidation and Hot Corrosion Beijing: Chemical Industry Press 2003: pp. 51-53.

26. Zhang, G., Guo, J., Ye, H. The Microstructure and Oxidation Behavior for NiAl-30.9Cr-3Mo-0.1Dy Alloy at High Temperature Journal of Aeronautical Materials 25 (02) 2005: pp. 6-11. http://ir.imr.ac.cn/handle/321006/25410

27. Hussain, N., Shahid, K.A., Khan, I.H., Rahman, S. Oxidation of High-Temperature Alloys (Superalloys) at Elevated Temperatures in Air: I Oxidation of Metals 41 (3-4) 1994: pp. 251-269. https://doi.org/10.1007/BF01080783

28. Xu, Y., Xia, T., Zhao, W., Wang, X., Yan, J. Activation Energy of Oxidation of Novel Co-Al-W Superalloys at High Temperatures Rare Metal Materials and Engineering 40 (04) 2011: pp. $701-704$.

29. Zheng, Y., Li, G., Xie, P. Kinetic Study of High Temperature Oxidation of Hot Dip Aluminizing Steel China Surface Engineering 14 (03) 2001: pp. 37-40.

30. Yang, Z., Lu, J., Li, Y., Le, M., Zhao, X. Oxidation Behavior of Two Austenitic Steels Used in $600{ }^{\circ} \mathrm{C}$ Supercritical Coal-Fired Power Plants Journal of Iron and Steel Research 29 (3) 2017: pp. 221-227.

31. Sundararajan, T., Kuroda, S., Kawakita, J., Seal, S. High Temperature Corrosion of Nanoceria Coated $9 \mathrm{Cr}-1 \mathrm{Mo}$
Ferritic Steel in Air and Steam Surface \& Coatings Technology 201 (6) 2006: pp. 2124-2130.

https://doi.org/10.1016/j.surfcoat.2006.02.007

32. Tian, S. G., Lu, X. D., Sun, Z. D. Internal Oxidation and Internal Nitridation of Ni-Base Alloy With High Cr Contents during High Temperature Exposure The Chinese Journal of Nonferrous Metals 22 (2) 2012: pp. 408 - 415.

33. Feng, C., Chen, E., Li, M., Wu, N. Effects of $\mathrm{Cu}$ Content on Microstructure and High-Temperature Oxidation Behavior of Ti-Al-Si-Cu-N Nanocomposite Films Rare Metal Materials and Engineering 46 (3) 2017: pp. 627-633. https://doi.org/10.1016/S1875-5372(17)30108-X

34. Sharafi, S., Farhang, M.R., Effect of Aluminizing on Surface Microstructure of An HH309 Stainless Steel Surface \& Coatings Technology $200(16-17)$ 2006: pp. $5048-5051$. https://doi.org/10.1016/j.surfcoat.2005.05.024

35. Gan, L., Gomez, R.D.,Castillo, A., Chen, P.J., Powell, C.J., Egelhoff, W.F. Ultra-thin Aluminum Oxide as a Thermal Oxidation Barrier on Metal Films Thin Solid Films 415 (1) 2002: pp. 219-223. https://doi.org/10.1016/S0040-6090(02)00622-3

36. Liu, P. S., Liang, K. M., Zhou, H. Y., Guan, H. R., Sun, X. F., Jin, T., Yang, K. N. Oxidation Behavior and Breakdown of an Aluminide Coating on DZ40M Alloy at High Temperatures Oxidation of Metals 55 (5-6) 2001: pp. $543-550$. https://doi.org/10.1023/A:1010363916459

37. Shi, Q., Liu, J., Wang, W., Yan, W., Shan, Y., Yang, K. High Temperature Oxidation Behavior of SIMP Steel Oxidation of Metals 83 (5-6) 2015: pp. 521-532. https://doi.org/10.1007/s11085-015-9532-9 